Article

\title{
Use of Prayer as Complementary Therapy by Christian Adults in the Bible Belt of the United States
}

\author{
Robbie Madden South *(D) and Liz McDowell (D) \\ William Preston Turner School of Nursing, Lander University, Greenwood, SC 29649, USA; \\ lmcdowell@lander.edu \\ * Correspondence: rsouth@lander.edu; Tel.: +1-864-923-2158
}

Received: 20 September 2018; Accepted: 2 November 2018; Published: 7 November 2018

check for updates

\begin{abstract}
Persons of all major religious groups use prayer as a spiritual discipline when dealing with sickness, and a majority of Christians report faith in healing prayer. The purpose of this research was to explore the use of prayer as complementary therapy for healing by Christian adults in the Bible Belt of the United States. A hermeneutic phenomenological approach was used in this qualitative study. This project was a secondary analysis of a larger study whose aim was to document stories of miraculous healings ( $n=14$ ). Open-ended questions focusing on participants' use of prayer followed the initial telling of their stories. All participants used prayer as complementary to their traditional medical treatments, and emerging themes included prayers of the people, rituals and traditions associated with prayer, prayers of supplication, and experiences related to the act of praying. These findings support prior published studies regarding the prevalence of prayer and its use as complementary therapy. Participants commonly used prayer in times of illness and the effects of prayer included a sense of wellbeing, increased calmness, decreased anxiety, and positive healing experiences. Participants utilized self-prayer and prayer support from family, friends, clergy, and healthcare professionals.
\end{abstract}

Keywords: prayer; healing; anointing; Bible Belt; complementary therapy

\section{Introduction}

Prayer as a spiritual discipline has been used by all major religious groups since ancient times. Prayer is defined as "a spiritual communion with God or an object of worship, as in supplication, thanksgiving, adoration, or confession" (Prayer 2018). The form or type of prayer may vary; however, Christians use prayer as compassionate care for the sick in their congregation or communities (Narayanasamy and Narayanasamy 2008). Supplication or petition is an often used form of prayer in Christian communities and is seen as a component of Christian service as directed by the Apostle Paul in Philippians 4:6 (New International Version): "Do not be anxious about anything, but in everything, by prayer and petition, with thanksgiving, present your requests to God". According to Zaleski and Zaleski (2005, p. 315), " ... healing prayer is a universal human prerogative, and it touches our deepest need-to feel our fragile existence supported and upheld by a wider and stronger reality".

The purpose of this qualitative research is to explore the use of prayer as a complementary therapy for healing by Christian adults in the Bible Belt of the United States. This study is a secondary analysis of data from a larger study by the same co-investigators of experiences of adults who have received miraculous or mysterious healings.

The traditional role of most Christian pastors includes prayers for members of the congregation. Linvall (2014), a Presbyterian minister, discussed prayer for members of his congregation and prayers in preparation for other ministerial responsibilities as routine components of pastoral duties. Kidder (2009) discussed the traditional role of pastors and included the first priority as spending time 
with the Father (God) as modeled by Jesus in his life of prayer evidenced in numerous scriptures including Matthew 21:13, "My house will be called a house of prayer". Another role of pastors discussed by Kidder (2009) was caregiving, such as visitation, counseling, comfort, and taking care of the needs of people. Vanghi (2016, p. 49) explains the purpose of prayer in his ministry: "Prayer is our most important way of living in the mercy of God. It is where we experience His love for us as we seek His mercy for another".

Barna Group conducted research in 2016 to understand the beliefs, practices, and experiences of American adults as they relate to supernatural healing. Their research also included information of prayer practices. Online interviews were conducted with a total of 1011 interviews. According to the results of the research, $68 \%$ of adults have personally prayed for someone to be healed supernaturally by God. Women (73\%) and evangelicals (95\%) are more likely to have prayed for someone to be healed, however $86 \%$ of practicing Christians expressed faith in healing prayer. More miraculous healings were reported in the Bible Belt of the United States (Southern region) as compared to other regions of the country (Barna Group 2016).

Using the 2010 Baylor Religion Survey ( $n=1714)$, Levin (2016) investigated the prevalence and religious indicators of healing prayer use among adults in the United States. The survey included five indicators: (a) prayed for self (lifetime prevalence 78.8\%); (b) prayed for others (87.4\%); (c) asked for prayer $(54.1 \%)$; (d) laying on of hands $(26.1 \%)$; and (e) participated in a prayer group $(53 \%)$. Levin states,

"According to these findings, use of healing prayer is not primarily something relied upon by poor, uneducated, rural folks, or old people, or people who are suffering from a health crisis or who are depressed or stressed out. It is not so much driven by social-structural disadvantage resulting in unmet health needs due to lack of healthcare access. Rather, use of healing prayer is largely a function of religiousness, in some form or another". (Levin 2016, p. 1153)

Jors et al. (2015) conducted a systematic review of the literature using the databases of PubMed, Medline, and PsychINFO to explore the use of private prayer by patients dealing with chronic illness. The content and purpose of the prayers was investigated rather than its effects. Disease-centered was the most common topic of prayers. Although most patients prayed for relief of suffering from disease, their prayers were not only for healing, but served as a resource to help them on their journey through sickness. The researchers concluded that prayers could serve as a coping strategy and therefore the study of prayer and its uses was clinically relevant in healthcare.

Parachin (2011) discussed a case study of a woman healed from a debilitating neurological condition after fervent self-prayer and prayer by others. He suggested that the healing of this woman is confirmation of the power of prayer. Parachin stated that prayer is the most commonly used form of alternative medicine and is also acknowledged by many physicians as contributing to healing of their patients.

McCaffrey et al. (2004) and colleagues of Harvard Medical School reported on the results of a national survey on prevalence and patterns of the use of prayer for health concerns $(n=2055)$. McCaffrey reported that $35 \%$ of respondents used prayer for health concerns and $22 \%$ prayed for specific medical conditions. Sixty-nine percent of those praying for specific medical conditions found prayer very helpful (McCaffrey et al. 2004).

Burnett-Zeigler et al. (2016) conducted a comprehensive literature review examining the evidence for the efficacy of mind-body interventions for mental health symptoms among disadvantaged populations. While rates of utilization were relatively lower for racial/ethnic minorities, evidence suggested that significant proportions of racial/ethnic minorities are using complementary health approaches (CHA) as health treatments, especially prayer/healers and natural or herbal remedies. The review found evidence for the efficacy of mind-body approaches for several mental and physical health symptoms, functioning, self-care, and overall quality of life. Among CHA users, racial/ethnic 
minorities reported higher rates of use of prayer, healers, and natural/herbal remedies as treatments for depression, anxiety, and other chronic health conditions.

Upchurch et al. (2010) conducted a study to investigate the most frequently used types of complementary and alternative medicine (CAM) therapy and the use of prayer for health among midlife women. The extent to which women used CAM for treatment of health conditions, including menopausal symptoms, and for general health and wellbeing was examined. Data from the 2002 National Health Interview Survey (NHIS), a cross-sectional, household survey representative of U.S. civilian adult population were used. The sample included midlife women aged 40-59 years of age $(n=5849)$. Fifty-four percent of the sample reported using prayer for health reasons. Although CAM and prayer were reported as frequently used by midlife women, prayer was not reported to be one of the top five specific CAM therapies used.

Pettigrew et al. (2004) administered a questionnaire at an outpatient clinic to 250 women to assess their knowledge and perceived effectiveness regarding the use of 20 complementary and alternative therapies. Their findings included:

- $69 \%$ used one or more complementary therapies

- $66 \%$ used prayer as a complementary therapy

- Prayer was one of the most frequently used complementary therapies

- $50 \%$ of the women using prayer used it for wellbeing

- Effectiveness of prayer was ranked as 4.33 on a scale of 1-5

Kemper (2016) discussed various types of healing practices including Therapeutic Touch, Healing Touch, Qigong, Reiki, and Healing Prayer. She noted that Christian healers may use laying on of hands and that prayer is often used to achieve a healing state. Christian healers usually view themselves as instruments for Divine healing power. Healers of various healing practices or traditions reported different sensations or effects while engaging in healing work. Some healers reported a sense of energy, heat, fullness, or tingling in their hands. Other healers reported feeling the discomfort or pain of the recipient of the healing work. Some recipients of healing practices reported a sense of energy or warmth during the healing experience. Many Christian churches include the prayer rituals of laying on of hands and anointing with oil and base their use on scriptures. In Mark 6:7-13 Jesus commissioned the disciples and gave them instructions to anoint the sick with oil. In James 5:14-15 (NIV) the elders of the church are to be called to anoint the sick and pray. The passage from James concludes with the prayer offered in faith will make the sick person well; the Lord will raise them up.

Prayer continues to be used by all major religious groups and by the majority of adults when addressing sickness. Prayers of petition by clergy, family members, and friends are often offered as support for those who are ill. The majority of practicing Christians express faith in healing prayers. Prayer is used by all racial, ethnic, and socio-economic groups; however, racial and ethnic minorities report using prayer more often for some mental health conditions. Prayer rituals such as anointing with oil and laying on of hands often accompany healing prayers. Prayer is one of the most common complimentary health approaches and serves as a coping strategy for sick individuals.

\section{Materials and Methods}

The aim of this qualitative research is to explore the use of prayer as complementary therapy in times of illness by Christians living in the Bible Belt of the United States. This current project is a secondary analysis of data from an ongoing study whose aim is to document the participants' stories of miraculous healings. Therefore, the participants $(n=14)$ were initially asked to tell their stories of healing. The methodology for this research project is also recorded by the co-investigators in their previous published research (McDowell and South 2017). 


\subsection{Qualitative Approach}

A hermeneutic phenomenological approach is used in this study and the approach is informed by the philosophies of Heidegger and Husserl. A phenomenological approach involves exploring experiences (Hopkins et al. 2017). More specifically, phenomenologists try to understand what phenomena or concepts mean by investigating participants' experiences of the phenomena (Hopkins et al. 2017). Heidegger's phenomenological aim was to interpret participants' experiences rather than just describe the experiences (Hopkins et al. 2017). Heidegger believed that as humans we are always interpreting what is around us, thus a central tenant to Heidegger's phenomenology is the notion of hermeneutics, or achieving understanding through interpretation (Hopkins et al. 2017).

Researchers approach their work with assumptions and beliefs about the phenomenon they are studying. In phenomenology, the researcher is the primary instrument for gathering data and interpreting data. Therefore, it is necessary for researchers to reflect upon, and state as clearly as possible, the assumptions and beliefs they bring to the research (Hopkins et al. 2017). The co-investigators in this research study are both nurses who teach nursing at a small liberal arts university in the southeastern United States. Both co-investigators practice the Christian faith and have experienced healings in their personal lives. Robbie Madden South is a professor emeritus and former school of nursing director. She is a member of a Southern Baptist church in a small town in the southeastern United States. Her primary nursing foci include community health nursing and spiritual care. She has also developed and taught a course in complementary therapies. Liz McDowell is an associate professor of nursing and has a Master of Divinity degree from Vanderbilt University. She is a member of the Episcopal Church. Her primary nursing foci include mental health nursing and leadership. The aim of these researchers' initial collaboration was to explore the stories of miraculous healings. However, it was noticed in the participants' telling of their stories that prayer played an integral part in their journeys of illness and recovery. Therefore, the focus of this particular research is the lived experience of the participants' use of prayer as complementary to their traditional medical treatment.

Husserl's perspective regarding phenomenology is that in order to expose the true essence of people's experiences, we must put all our pre-understandings aside so as to focus on the research participants' experiences, a process also known as "bracketing" (Hopkins et al. 2017). The co-investigators in this research study accept Husserl's perspective. However, they also believe, like Heidegger, that complete objectivity is impossible. Rather than eliminating subjectivity, researchers' subjectivity should be managed with reflexivity - the noting, tracking, questioning, and sharing of the ways we shape and are shaped by the research process (Hopkins et al. 2017). Prior to initiating this research project the co-investigators spent time discussing their thoughts, beliefs, and suppositions regarding spirituality, healings, and prayer. These discussions between the co-investigators continued throughout the data collection and data analysis processes. The processes of bracketing and reflexivity allowed the co-investigators to remain open to the data as it was revealed while also using their previous knowledge to help them better understand the phenomenon.

\subsection{Ethical Issues Pertaining to Human Subjects}

The research protocol was reviewed and approved by the Lander University Institutional Review Board (IRB) in September, 2016, prior to initiating data collection. The research was conducted in accordance with the Declaration of Helsinki and the researchers were committed to abide by the Federal Policy (Common Rule) for the Protection of Humans Subjects (45 CFR 46). The institution protocol number for this study is 2016-2. The IRB reviewed the research protocol again in October, 2017, and permission was granted to continue collecting data. 


\subsection{Sampling Strategy}

The researchers knew the initial participants and the majority of the remaining participants $(n=14)$ were recruited through snowball referrals. One participant was contacted following an Internet search. Sampling was purposive and included persons who had experienced healings, family of persons who had experienced healings, and persons who operated in the role of healers including pastors and a retired doctor. All of the participants included in this secondary research project were also part of the original research project. After giving their informed consent, participants were interviewed by the co-investigators in a place convenient and comfortable for the participants (in their homes, offices, restaurants, by telephone, or in the home of one of the researchers).

All participants, ages 22 to 88 , practice the Christian faith with the majority being members of Baptist churches $(n=7)$. Four participants are members of Pentecostal churches. Ten participants are professionals (including health care personnel and pastors), and three participants are maintenance workers. All participants identify as Caucasian, and are divided equally as to gender. All of the participants are residents of a southern region of the United States known as the "Bible Belt". In the United States, the term "Bible Belt" generally pertains to a region that stretches from northern Texas to western North Carolina, and from Mississippi to Kentucky and is associated with fundamentalist Protestantism, puritanical mores, social conservatism, and a belief in the literal interpretation of the Bible (Brunn et al. 2011; McDowell and South 2017; Sahl and Batson 2011). This region differs from other regions because it has a distinct culture based on church involvement and religious ideology (Sahl and Batson 2011). A total of 15 participants were interviewed before saturation was achieved. One participant in the original study did not meet the criteria of living in the Bible Belt region of the United States during the time of his illness and treatment and therefore was not included in this current study.

\subsection{Data Collection and Analysis}

A hermeneutic phenomenological approach was used in this research project. Open-ended questions facilitated the collection of the participants' experiences of healing. Open-ended questions allow participants to share their experiences in their own words rather than being forced into pre-established lines of thinking developed by the researchers (McDowell and South 2017; Streubert and Carpenter 2011). The interviews began with the primary open-ended request "to share your experiences with healing and healing miracles" (McDowell and South 2017). Follow-up questions regarding the role of prayer in their experiences provided narrative text that became the focus of this analysis: "What are your personal beliefs regarding healing miracles and healing ministries? Do you think prayer contributed to your healing experience? If so, describe how prayer contributed to the experience".

Each interview lasted between 30 and $90 \mathrm{~min}$ and both co-investigators conducted all the interviews. Following each interview, the transcripts were typed and reviewed for accuracy. The initial notes taken during the interviews and the typed transcripts are stored in a locked cabinet at the university and are only accessible to the co-investigators. The paper trail also includes notes taken during analysis of the data and grids demonstrating the theme discoveries (McDowell and South 2017). Typed transcripts and theme analysis grids are also kept in a computer data base that is password protected and only accessible to the co-investigators. The objective of the paper trail is to illustrate as clearly as possible the evidence and thought processes that led to the conclusions thus enhancing the trustworthiness of the findings (McDowell and South 2017; Streubert and Carpenter 2011). Data analysis began with the initial interview in November 2016 and was on going through the writing of this article. The interpretation involved reflecting on the initial reading and repeated readings searching for prominent themes related to prayer. 


\section{Results}

In the analysis of the qualitative data gathered from the telling of the participants' stories of healing, the use of prayer emerged as a prominent theme. As discovered through a review of the literature, prayer is one of the most common forms of complementary therapy (Parachin 2011; Pettigrew et al. 2004; Upchurch et al. 2010) and prayer is more likely believed to be instrumental in healing in the Bible Belt (Barna Group 2016). All of the participants in this study included prayer as complementary to their traditional medical treatments, and the emerging themes included prayers of the people (self-prayer, and prayers of the family, clergy, church family, friends, faith communities and healthcare professionals); rituals and traditions associated with prayer (anointing, laying on of hands, healing services, and quoting scriptures); prayers of supplication (intercessory and petitionary); and experiences related to the act of praying (faith, visions, physical manifestations, and feelings of calmness, comfort, and peace).

\subsection{Prayers of the People}

Without prompting all participants $(n=14)$ mentioned prayer in the initial telling of their healing stories. The most common prayers mentioned were either self-prayers or prayers by churches, communities, friends, family, and pastors. Only after prompting for more information did three participants state that their nurses prayed for them and four participants stated their doctors had offered prayer on their behalf.

\subsubsection{Self-Prayer}

J.C., a retired police officer, suffered with heart disease and had triple-bypass surgery. He described his mother as "blessed" and stated "she made us go to church". He recalled her teachings during his own illness and stated "I prayed a lot". NH, an 88-year-old retired nurse who is known as a "prayer warrior" in her community, provided an example of self-prayer. Following an accident, she spent time in the intensive care unit:

I was put to sleep and my heart began to cut up. They put me in ICU. I knew something was wrong and I began to pray: "Lord, I'm ready. Take me home". A friend was sitting with me. She said I prayed all night long. I knew something was wrong but didn't know what it was.

Regarding her current prayer life, N.H. stated: "I just love to pray. I think we need to pray more".

\subsubsection{Prayers of the Family}

L.S. is a nurse and mother of twin sons. When her sons were in college, one was diagnosed with esophageal cancer. L.S. described how fervently she prayed for him:

I remember that day so good. I had been in prayer the whole time. People that I knew at home were praying. Many different churches were praying. I didn't stop-prayed without ceasing ... . I was trying to keep him calm. My best friend was there. We had prayer with him .... My husband was doing the same .... It seems like every time I turned around someone was praying for him.

\subsubsection{Prayers of the Clergy}

M.T., who describes herself as a Methodist and cancer survivor, talked about the prayers of her pastors and family in the initial telling of her story:

I'm Methodist, so we have had many preachers—but each preacher carried on with prayers and prayer chains. The first preacher was there for my surgery and was with my family .... . The second preacher came during the following summer and carried on with the prayers. Of course, my family continued to pray. When my family traveled they put my name on the Great Wall .... I don't know how people live without prayer and God. 
M.W. shared the writings of her son whose grandfather was ill. He described the prayer of a friend who was also a pastor. The pastor prayed the following:

God, you know how much Brother M. means to all these widow ladies. He never charges them anything .... there are so many who depend on him to do repair work for them. God, they need him, but you do whatever is in your will. Thank you, God. Amen.

\subsubsection{Prayers of Friends, Churches, and Faith Communities}

J.W., a young mother whose son had been diagnosed with Hemolytic-Uremic Syndrome (HUS), was surrounded with prayers and support from many churches and faith communities in the area.

Tuesday evening my husband got there. We were sitting on the bench looking at a phone. Somebody grabbed our arms. It was our friend, M. "Please tell me it is not your son". Other children in the daycare had E. Coli, but not HUS. I think she felt a lot of guilt. I don't think they were thinking it came from the day care. She was emotional; she cried. The next night she came to our room with her pastor. She had just lost her son, but she was so worried about my son. They are praying with us and over our son. I'm thinking he is going to die, too. They can't give anything to treat it. They just gave him blood. We had been there a week. People were praying, but he was getting worse .... We were visited by other clergy .... . People I didn't even know were praying. They came out of the woodwork. One pastor I didn't even know waited for a long time for my son to come back to his room so he could pray for him.

L.N., a senior pastor, told his church on a Sunday that he would be having surgery for breast cancer the following Monday.

I didn't tell a lot of people. It happened so quickly. R. told the executive committee. The church here prayed. The minister of music ... and the church prayed on Sunday before Monday's surgery. It was special that this church was praying.

M.W., a Baptist, shared her father's story of cancer treatment. She stated that her father did not believe "it was his time to go". She stated that "he prayed for himself and the church prayed. I don't remember putting his name on a prayer list".

\subsubsection{Prayers of Healthcare Professionals}

L.S. acknowledged the prayers of healthcare professionals and the comfort the prayers provided during her medical emergencies.

The most comfortable I've felt was when I've had nurses come pray with me. I broke my arm and my doctor was doing an open reduction. He asked me if he could pray for me. I also had an aortic valve replacement and a male nurse prayed for me.

A surgeon, M.S., admitted initial timidity in praying for his patients. But he eventually opened his own practice stating it was a "Christian practice" where he "performed the best surgery and I prayed, too".

I could tell you story after story. People from my church would come to me. I had a man who came for carotid surgery. You have to be very precise because blood flow is cut from the brain. We had prayer in the holding area before surgery. I told his family not to go to the gift shop or watch TV, but to just pray for us. During surgery I felt like I was not in control of my hands because I can't operate this good. I contribute it to the fact that faithful people were praying. 
C.W., an oncology nurse, fought her own battle with Hodgkin's disease. She talked about prayer from the view of the patient and from the perspective of the nurse. She stated that she selectively prays for her patients, waiting for cues from them regarding their spiritual care: "I pray with my patients and for my patients. I get a sense from my patients about prayer".

\subsection{Prayer Rituals and Traditions}

Many of the participants in this study described various prayer rituals and traditions associated with their acts of prayer for healing. The most prominent traditions included anointing the sick and laying on of hands, attending healing services, and quoting scriptures.

\subsubsection{Anointing of the Sick and the Laying on of Hands}

According to the Christian faith, Jesus had a particular concern for the sick and healed them with the power of the word and with the human and compassionate touch (Tufano 2011). When Christians are sick, prayer appears to be the basic method of seeking God's help and guidance (Austin 2015). But Christians can also request the rituals described as the "laying on of hands" and "anointing with oil" along with prayers. In the Catholic tradition, anointing of the sick is used to offer strength and healing in times of serious illness (Tufano 2011). Spiritual and physical healing are often sought through prayer, touch, and anointing with oil and instructions for the anointing of the sick with oil have been found engraved on a silver plate dating from the early second century (King 2015). The typical instructions include the thumb being dipped into oil and the sign of the cross made on the petitioner's forehead. Then hands are laid upon the sick person and a prayer is offered (Austin 2015).

Five of the participants stated that in addition to prayers, they also experienced the Christian rituals of anointing with oil and / or the laying on of hands. In addition to the prayers of family, friends, and pastors, J.M. described the rituals of anointing and laying on of hands during his illness:

The heart episode was eight or nine years ago .... People prayed ... . My sister came in.

They were around the bed praying .... Pastors prayed, anointed me, laid hands on me ....

I had the Sunday School class pray for me.

L.N., a pastor diagnosed with breast cancer, stated he was "walking in the prayers of God's people". He also said, "The church here prayed. The minister of music anointed me and the church prayed". J.C., a former police officer, stated that ministers prayed for him and some of them anointed him throughout his numerous illnesses. R.H., a layperson, personally experienced the healing prayers of others and has offered healing prayers to those in need. He demonstrated the importance of the ritual of anointing with oil with this description:

When I felt the presence of God my hands would get hot. At work, my hands were getting hot and a man came around the corner-he had a tumor on his pituitary. We didn't have any anointing oil, so we used machine oil. I anointed him and prayed and told him he was healed. He went ahead and had the surgery, but they found no tumor. He was actually mad. He had gauze all up in his nose and all, and he said to me, "I wish I had listened to you".

On a separate occasion, R.H. stated a man at church told him that he was in pain and that his leg was hurting:

We prayed. After church he came to me and said he was still hurting. We anointed his knee and prayed some more. I've never done this before but I said, "When you get up in the morning and touch the floor, you will have no more pain". The next day he called and said, "The pain was killing me when I woke up, but when I touched the floor the pain was gone".

M.S., a retired general surgeon, often prays for his patients when requested. He described praying for a patient who was a good friend and anointing him with oil: 
I operated on him and he was full of cancer. I went to see him and prayed for him in the name of Jesus. They were planning to send him home the next day, but he had to drink something first. When he started to drink, he got really bad and had to go to the ICU. I went in and held him, anointed him with oil, and prayed in the name of Jesus.

\subsubsection{Healing Services}

Many people think of a healing service as a large, boisterous crowd led by a charismatic leader who claims to have supernatural powers. However, prayer for healing has occurred in churches since the first century and most current Christian healing services stray from this stereotype (Brown 2006). C.W. was diagnosed with Hodgkin's lymphoma in 1997 while she was in nursing school. She described her experience of seeking spiritual care after hearing that her traditional medical treatment had not been as effective as the medical team had hoped. She attended a special church service where she was anointed with oil and experienced the laying on of hands as a prayer ritual.

The plan was to increase the radiation and to explore other options. There was a healing service scheduled at the First Baptist Church. I wanted to go to that healing service. I knew God could heal me. I was determined to go to that service. They had one that week. We went. I went up to the front. The pastor and other people prayed. The pastor anointed me with oil. It was an amazing feeling.

T.P., a retired pastor in the Assembly of God church, recalled an experience of prayer, anointing, and scripture reading.

There were close to forty people gathered to pray for the upcoming church services and for the lost to be saved and, of course, for the sick to be healed. There were people all over the house with standing room only. I forgot who read the scriptures from the Bible, but I remember we began to pray and as we prayed we laid hands and anointed with oil those who were sick or just asking for prayer for their loved ones who needed to be saved or were sick.

M.S. is a retired general surgeon and long-time member of The International Order of St. Luke (OSL). Christian clergy, health professionals, and lay people who feel called to the ministry of healing are invited to become members of OSL (OSL 2018). MS described his ministry as including healing services and healing conferences.

Right now I'm doing clinic practice and Wednesday and Thursday prayer groups. We also do individual prayers and we train others for prayer ministry. We have had major healing conferences. This Saturday we are going to have a healing service. We have a format we use. We've modified it some. The prayer minister gets there one hour early to pray and prepare. We have praise and worship for 30 to $40 \mathrm{~min}$ and then teaching from God about healing. We have communion, soaking prayer, and individual prayer-for physical, emotional, and generational needs.

\subsubsection{Quoting Scripture}

Pentecostal ministers teach the benefit of quoting scriptures as a strategy for receiving and/or maintaining healing. Copeland and Copeland (2009) recommend reading scriptures continually to keep one's faith strong for healing. The list of recommended scriptures were originally compiled by Dodie Osteen who was healed from terminal liver cancer many years ago. She read the scriptures as a daily "medicine" until all symptoms of cancer were gone (Copeland and Copeland 2009). S.G., a retired Pentecostal pastor, and R.H., a layperson, both relied on quoting scriptures during their prayers. R.H., having been diagnosed with a brain lesion, was being transported in an ambulance with a Mennonite nurse and paramedic. 
I turned my head to the wall and said, "God, I need a word". God spoke Romans 8:28 vividly and clear: And we know that all things work together for good to them that love God, to them who are the called according to his purpose. I knew in my spirit everything was going to be fine.

R.H. also recited scriptures regularly when praying for his wife who had been diagnosed with cancer. He had been watching an evangelist on television who stressed the importance of "speaking scriptures over the sick person".

I spoke those scriptures over her and she was healed. I prayed for me and my wife for five years once a day. It got to the point where the Bible just opened to those scriptures. Most scriptures I've memorized are the King James Version. It is just etched in my mind. I remember me and the preacher going to Charleston to see this sick man and I read those scriptures. I was so full of faith when we got to Charleston-that man walked out of the hospital.

S.G. stated he had a friend in the hospital who was "very sick with Rocky Mountain Spotted Fever".

I went to visit him and picked up the Gideon Bible beside him. "J., do you believe this book?" He said, "Yes". Then I read from Matthew and prayed: "If we believe and doubt not, we will have". His fever started going down. God instantly healed him. He went home the next day.

\subsection{Prayers of Supplication}

Prayer as a spiritual discipline is an essential component of Christian's lives. Numerous Bible passages give instructions to pray. The Apostle Paul instructs in I Thessalonians 5:17 (New King James Version), "Pray without ceasing". Jesus instructed the disciples in Matthew 26:41 (NKJV), "Watch and pray, lest you enter into temptation". James speaks directly regarding healing prayers in James 5:15 (NKJV), "And the prayer of faith will save the sick and the Lord will raise him up" and in James 5:16 (NKJV), " . . pray for one another, that you may be healed. The effective, fervent prayer of a righteous man avails much". Supplication or petition prayer is the most common type of prayer described by the participants in this study (Supplication 2018). Intercessory prayer, a type of petition prayer, is prayer on behalf of others (Intercession 2018).

\subsubsection{Intercessory Prayer}

The Bible contains many examples of intercessory prayers in both the Old and New Testaments. Abraham prayed for the city of Sodom in Genesis 18:23-33. Moses prayed for the healing of Miriam's leprosy in Numbers 12:13. Elijah the prophet prayed for the widow's son in I Kings 17:20. Job offered intercessory prayers for his children in Job 1:5. Examples from the New Testament include Jesus's intercession for those who crucified him in Luke 23:34. The early Christian church prayed for the Apostle Peter in Acts 12:5 and 12 when he was imprisoned.

Most of the exemplars presented from this research data include some type of intercessory prayer. Family, friends, church members, clergy, and healthcare workers prayed for someone else in need. In addition to the intercessory prayers presented within the other identified themes, J.M. described intercessory prayer offered on his behalf by his wife, sister, and pastor. J.M. is a 75-year-old white male and member of a Pentecostal Holiness church. Describing his experience with a life-threatening medical situation, he stated that the last thing he remembered was hearing a command to "call a code blue".

I woke up two days later on life support. A large blood clot had formed in my leg. It went to my heart and lungs. I would not have made it if I had not been in the hospital on the heart floor. My doctor did not think I would make it. He told my wife that he didn't think I would make it. All my organs shut down. Only the machines were keeping me alive. 
The doctor was basically telling my wife that I would not make it, but she said, "You don't get to decide". Then the doctor looked and could see that my kidneys had begun to work. (I was unconscious through all of this). I don't remember any of this. My sister came in. They were around the bed praying and bargaining with God. People prayed. Pastors prayed, anointed me, and laid hands on me. The doctors had given up on me. But when people pray, things happen.

\subsubsection{Petitionary Prayer}

Petitionary prayer is what the apostle Paul asked Christians to do in Philippians 4:6 (King James Version), "in everything by prayer and supplication with thanksgiving let your requests be made known unto God". Most of the intercessory prayers described by the research participants were petitionary. Some of the petitionary prayers appeared desperate. L.S., petitioning on behalf of her sick son, prayed a prayer of petition: "We had prayer with him. While he was back there I walked up and down the hall. 'Lord, if someone has to have cancer, give it to me.' My husband was doing the same". A young man recounted the prayer experience for his sick grandfather in this way:

Silently I prayed, “Oh God, please don't let him die. He's done so much for so many. He's a Christian man, but then, you know that. He and Nannie have raised two children and worked so hard, all their lives. You've seen all the people for whom he has unlocked houses and cars during the early morning hours. But God, I don't have to tell you all this. You already know it. There's one thing you may not know ... I love Papa very much. Please don't take him away. I have so much yet to learn from him. Please, God, please".

J.W., a young mother praying for her very sick son stated that many of her prayers were: "Oh God, please God".

\subsection{Prayer Experiences}

Christians from various religious traditions include prayer as an important spiritual practice. A book of common prayers is used by some Christians as a daily prayer ritual. Vespers or an evening prayer service may be attended by members of a faith community. An impression or an internal prompting to pray for family or friends in need has been reported by some Christians. The need to have faith in God to answer prayer is recognized by practicing Christians and is based on Jesus's words from Matthew 17:20 (King James Version), “... If ye have faith as a grain of mustard seed, ye shall say unto this mountain, remove hence to yonder place; and it shall remove; and nothing shall be impossible unto you". Some individuals report visions or supernatural manifestations during or after a prayer episode. How a transcendent experience affects an individual may vary among Christians and may change on different days.

\subsubsection{Experiencing an Impression to Pray}

Some participants expressed feeling an urge to pray for others within themselves. Nielsen (2013) discussed ways to recognize a prayer burden, or an impression to pray for someone. He stated that a prayer burden is: (a) a peculiar compassion; (b) an unselfish concern; (c) an inner voice or impression, (d) a special personal assignment; and (e) intense and urgent determination (Nielsen 2013).

L.N., a senior pastor and father was impressed upon to pray for his son's 17-year-old friend. This friend had attempted suicide by overdose and was not expected to live.

My son wanted me to pray. I have a place in my living room and a rocking recliner. I felt encouraged to pray. Let me preface this. We all pray for people to be healed. Most of the time we don't get answers. This time the Lord whispered to me, "Pray for healing". The Lord's speaking was more of an impression. This young man walked out of the hospital the next morning. 
L.N. at one time was the director of a counseling center. He had an employee who developed meningitis. After visiting her, he still felt an impression to continue to pray for her.

She was in the local hospital. Her face was puffy and her speech was slurred. The doctor did not expect a recovery and told her to apply for disability. I prayed for her and left. The Lord clearly spoke to me and told me to pray for her to be healed. Her healing was slow, but she is fine now.

T.P., a retired Assembly of God pastor, described having a "burden to pray" for a friend.

When I woke up the next morning I had a real burden for a friend of mine. I could not stop thinking about him .... I'll tell you, when someone or something is on your mind and your heart you really need to ask the Holy Spirit what He wants you to do. I did, and as I started praying it was like a still small voice inside me that said, "I'm going to heal Mr. B. today and I want you to go pray for him". ... I keep praying asking "Are you sure?" Over and over, "You go and I'll heal him".... I told my wife I was going to go and pray for him. She just said, "Ok". All the way over there I prayed in the Holy Ghost. I was still praying when I knocked on the door.

\subsubsection{Having Faith in Prayer}

Some participants expressed the importance of having faith in the power of prayer while others admitted their lack of faith while praying. Nielsen (2017) discussed three prayer directives to inspire faith by praying according to a promise in the Scripture, by praying specifically, and by praying with persistence.

R.G., a minister suffering with a kidney stone, admitted to "throwing my name in there" for healing prayer as if he was not expecting results, but felt he had nothing to lose. However, this same minister while visiting a friend in the hospital stated that he "read from Matthew and prayed. If we believe and doubt not, we will have". J.W., also expressed lack of faith during the illness of her young son. She stated, "I believed in prayer but when you're going through it, I didn't know if He heard us or not. Because when your doctors say they can't tell you he is going to be okay". Another participant, while in the intensive care unit, stated, "I knew He was going to heal me, so I didn't worry about it". J.M. concluded his narrative by stating, "When people pray, things happen". R.H. described many experiences praying for himself and others, often speaking scriptures while praying.

The pastor and I were going to Charleston to visit a sick friend in the hospital. I read those scriptures and I was so full of faith when I got to the hospital that the man walked right out of the hospital.

L.N., a Baptist minister, declared confidence in prayer. He stated, "I know God heals. I don't have any doubt. There is more going on than people think. We have a problem with the unseen realm".

\subsubsection{Experiencing Visions and Physical Manifestations}

The Bible contains many references in both the Old and New Testaments to visions and manifestations during times of prayer. Joel 2:28 (King James Version) states, "And it shall come to pass afterward, that I will pour out my spirit upon all flesh; and your sons and your daughters shall prophesy, your old men shall dream dreams, your young men shall see visions". Moses, Daniel, and Isaiah are all examples of Old Testament believers who received visions from God. In the New Testament in Acts 9 the Apostle Paul had a vision of Christ during his Damascus Road experience. In Acts chapter 10 Peter and Cornelius received visions during times of prayer and meditation that provided instructions regarding preaching the message of Christ to the Gentiles. John describes the vision he received on the Isle of Patmos recorded in The Revelation. A modern-day Christian, Hagin (1972) recorded numerous visions of Jesus during times of prayer and while conducting healing 
services. Hagin (1972) also experienced feelings of fire in his hands while praying for others and anointing them for healing. Four research participants described experiences of visions and other physical manifestations.

J.C., a 71-year-old retired police officer, had brain surgery to remove a tumor and was recuperating in the hospital. The doctors were preparing to move him out of the intensive care unit when J.C. developed complications.

My wife and daughter came on Thursday and Friday to see me. Friday I told them they needed to go home. They left. I watched TV and went to sleep. I wasn't hurting. I talked to a couple of nurses. A little past $2 \mathrm{AM}$, the door opened and Jesus walked in and sat on the left side of my bed. He said, "You are having a rough time. You have been. But you never accepted me. Don't you think it is about time?" ... We prayed and prayed. He prayed and I prayed ... . It was real. It was not a hallucination.

R.H. stated that often his hands would feel hot when he felt the presence of God. He would then pray for the sick person and lay hands on that person.

When I felt the presence of God my hands would get hot. At work, my hands were getting hot. A man came around the corner-he had a tumor on his pituitary.

R.H. also told the story of his own serious illness, a lesion on his brain stem. During his self-prayers he experienced a vision: "On Wednesday I got my bath and started praying. I could see my brain stem and could see this thing disappearing. This went on for about a minute". C.W., stated the following regarding a healing service where she was requesting prayer, "A different feeling came over me-chills or the Holy Spirit. It is very difficult to describe".

M.S., a 77-year-old retired general surgeon, described physical manifestations during prayers for a patient.

In the 90's I was operating on a man with cancer. His tumor was too big and too complex to remove. I did a reverting colostomy and planned to send him for chemo and radiation. I went to the patient's room and told the family. They were distraught. I didn't know what to do. In my mind I said, "God, I don't know what to do". Then I told the family, "He is alive and has a chance, and before he didn't". The family said, "Would you pray?" I didn't know what to say or do. But I started praying a beautiful prayer. I don't know where it came from. The walls began to shake and there was an intense white light in the room. Peace filled the room. People were hugging and thanking me. The patient went for chemo and radiation-but he was totally healed. There was no sign of cancer.

\subsubsection{Feelings of Calmness, Comfort, and Peace}

The benefits of prayer are well documented in both theological and academic circles. Jantos and Kiat (2007) discussed the positive emotions that prayer engenders and suggested that one's "relaxation response" created by prayer enhances a sense of wellbeing. Participants in this project confirmed this sense of calmness from prayer. M.T., an 86-year-old Methodist woman, battled ovarian and uterine cancer 31 years ago. She stated prayer played a "big role" in her recovery. She shared that her family prayed for her and "they had such a good feeling about the outcome. I don't know how people live without prayer and God".

A grandson praying for his sick grandfather stated: "An unexplainable peace fell over me after I prayed, a peace which allowed me to see what was happening yet somehow to know everything was going to be fine". L.S. is a 58-year-old Baptist who is also a nurse. She described her experiences of health care personnel praying for her prior to surgery.

The most comfortable I felt was when I've had nurses come pray with me. I broke my arm and Dr. L. was doing open reduction. Dr. L. asked me if he could pray for me. I had an aortic 
valve replacement/aneurysm and I had a male nurse pray for me. It was very calming. I was never scared during that surgery. Just having that doctor pray-same thing about the nurse.

\section{Discussion}

The use of prayer as a complementary approach to healing was reported by all the participants in this research study. One hundred percent of participants had support systems including family, friends, and clergy who were willing to offer their prayers on behalf of those in need. The participants' perceived the positive effects of prayer as a sense of wellbeing, increased calmness, decreased anxiety, and as an avenue to healing. Participants also reported the practice of prayer rituals, including anointing with oil, laying on of hands and quoting scriptures. The findings of this study support the research in the literature regarding the prevalence of prayer and its use as a complementary therapy for those seeking healing.

Holistic nursing includes attention to the body, mind, and spirit of clients. A spiritual assessment and spiritual care strategies are important interventions for addressing the spiritual needs of patients. Research studies have shown that prayer, both self-prayer and intercessory prayer, promotes healing and may inspire hope in patients (Ameling 2000; Hubbartt et al. 2012; Olver and Dutney 2012). Prayer is a spiritual care strategy that is frequently used by Christian adults and therefore should be considered as an appropriate intervention by nursing staff.

\section{Trustworthiness and Limitations of Findings}

In qualitative studies, the establishment of the trustworthiness of the findings is important. In other words, the findings should be credible, transferable, confirmable, and dependable. Prolonged engagement with the texts of the participants' interviews by the researchers helped to establish the credibility of the findings in this study. Confirmability was established by the practice of bracketing and keeping a detailed audit trail that highlighted the steps in data analysis. The methodological approach of this study is detailed in this manuscript so that the approach can be replicated by other researchers, thus establishing dependability. Replicating this research with different populations would contribute to the body of knowledge regarding the use of prayer as complementary therapy. And finally, the findings are transferable or applicable to similar situations and populations. Transferability, rather than generalizability, is desirable in qualitative research and was established in this study through purposeful sampling. The researchers were clear that they were working with a specific population (Christians in the Bible Belt) and were not attempting to generalize the findings to any other population. It should also be noted that all of the participants were recruited for an initial research project examining the stories of persons who stated they had experienced miraculous healings or were experiencing a positive healing journey. The analysis of the stories of persons using prayer as a complement to traditional medicine who had less successful outcomes might result in differing themes.

Author Contributions: Conceptualization, R.M.S. and L.M.; Data curation, L.M.; Formal analysis, R.M.S. and L.M.; Investigation, R.M.S. and L.M.; Methodology, R.M.S. and L.M.; Project administration, R.M.S. and L.M.; Validation, R.M.S. and L.M.; Writing—original draft, R.M.S. and L.M.; Writing—review \& editing, R.M.S. and L.M.

Funding: This research received no external funding.

Conflicts of Interest: The authors declare no conflict of interest.

\section{References}

Ameling, Ann. 2000. Prayer: An Ancient Healing Practice Becomes New Again. Holistic Nursing Practice 14: 40-48. [CrossRef] [PubMed]

Austin, Victor Lee. 2015. How to be a Sick Christian. First Things: A Monthly Journal of Religion and Public Life 249: 17-19.

Barna Group. 2016. Most Americans Believe in Supernatural Healing. Available online: https://www.barna.com/ research/americans-believe-supernatural-healing/ (accessed on 15 March 2018). 
Brown, Candy Gunther. 2006. From Tent Meeting and Store-front Meeting Rooms to Walmart and the Internet: Healing Spaces in the United States, the Americas, and the World, 1906-2006. Church History 75: 631-47. [CrossRef]

Brunn, Stanley D., Gerald R. Webster, and J. Clark Archer. 2011. The Bible Belt in a Changing South: Shrinking, Relocating, and Multiple Buckles. Southeastern Geographer 51: 513-49. [CrossRef]

Burnett-Zeigler, Inger, Stephanie Schuette, David Victorson, and Katherine L. Wisner. 2016. Mind-Body Approaches to Treating Mental Health Symptoms among Disadvantaged Populations: A Comprehensive Review. The Journal of Alternative and Complementary Medicine 22: 115-24. [CrossRef] [PubMed]

Copeland, Kenneth, and Gloria Copeland. 2009. Healing Wellness: Your 10-Day Spiritual Action Plan. Fort Worth: Kenneth Copeland Publications.

Hagin, Kenneth E. 1972. I Believe in Visions. Old Tappan: Fleming H. Revell Co.

Hopkins, Robin M., Glenn Regehr, and Daniel D. Pratt. 2017. A Framework for Negotiating Positionality in Phenomenological Research. Medical Teacher 39: 20-25. [CrossRef] [PubMed]

Hubbartt, Beth, Denise Corey, and Donald D. Kautz. 2012. Prayer at the Bedside. International Journal for Human Caring 16: 42-47. [CrossRef]

Intercession. 2018. Available online: https://www.biblestudytools.com/encyclopedias/isbe/intercession.html (accessed on 15 March 2018).

Jantos, Marek, and Hosen Kiat. 2007. Prayer as Medicine: How Much Have We Learned? Medical Journal of Australia 186: S51-S53. [PubMed]

Jors, Karin, Arndt Büssing, Niels Christian Hvidt, and Klaus Baumann. 2015. Personal Prayer in Patients Dealing with Chronic Illness: A review of the Research Literature. Evidence-Based Complementary and Alternative Medicine. [CrossRef] [PubMed]

Kemper, Kathi J. 2016. Authenic Healing: Effects on Recipients and Healers. Alternative and Complementary Therapies 22: 105-10. [CrossRef]

Kidder, S. Joseph. 2009. The Biblical Role of the Pastor. Ministry: International Journal for Pastors 81: $19-21$.

King, Bill. 2015. What is the Anointing of the Sick? Catholic Answer 28: 22-24.

Levin, Jeff. 2016. Prevalence and Religious Predictors of Healing Prayer Use in the USA: Findings from the Baylor Religion Survey. Journal of Religious Health 55: 1136-58. [CrossRef] [PubMed]

Linvall, Michael. 2014. Prayer on the Go. Christian Century 131: 11-13.

McCaffrey, Anne M., David M. Eisenberg, Anna T. R. Legedza, Roger B. Davis, and Russell S. Phillips. 2004. Prayer for Health Concerns: Results of a National Survey on Prevalence and Patterns of Use. Internal Medicine 164: 858-62. [CrossRef] [PubMed]

McDowell, Liz, and Robbie Madden South. 2017. Christians' Perceptions of Receiving Spiritual Care in the Bible Belt of the United States: A Qualitative Study of Care Provided in the Healthcare Setting. Religions 8: 127. [CrossRef]

Narayanasamy, Aru, and Mani Narayanasamy. 2008. The Healing Power of Prayer and its Implications for Nursing. British Journal of Nursing 17: 394-98. [CrossRef] [PubMed]

Nielsen, Stephen. 2013. Five Ways to Recognize a Prayer Burden. Available online: https:/ /studyingprayer.com/ 2013/03/27 / five-ways-to-recognize-a-prayer-burden/ (accessed on 27 June 2018).

Nielsen, Stephen. 2017. Three Prayer Directives That Will Inspire Great Faith. Available online: https:// studyingprayer.com/?s=prayer+directives (accessed on 27 June 2018).

Olver, Ian N., and Andrew Dutney. 2012. A Randomized, Blinded Study of the Impact of Intercessory Prayer on Spiritual Well-being in Patients with Cancer. Alternative Therapies 18: 18-27.

OSL. 2018. Available online: https: / / orderofstluke.org/en/ (accessed on 3 July 2018).

Parachin, Victor M. 2011. The Healing Power of Prayer. Vibrant Life 27: 28-31.

Pettigrew, Amy C., Margaret O’brien King, Karen McGee, and Connie Rudolph. 2004. Complementary Therapy Use by Women's Health Clinic Clients. Alternative Therapies 10: 50-55.

Prayer. 2018. Available online: http:/ / www.dictionary.com/browse/prayer (accessed on 27 June 2018).

Sahl, Allison Heard, and Christie D. Batson. 2011. Race and Religion in the Bible Belt: Parental Attitudes Toward Interfaith Relationships. Sociological Spectrum 31: 444-65. [CrossRef]

Streubert, Helen J., and Dona Rinaldi Carpenter. 2011. Qualitative Research in Nursing: Advancing the Humanistic Imperative, 5th ed. Philadelphia: Wolters Kluwer/Lippincott Williams \& Wilkins. 
Supplication. 2018. Available online: https://www.biblestudytools.com/dictionary/supplication/ (accessed on 27 June 2018).

Tufano, Victoria M. 2011. Why Do We Anoint the Sick? U. S. Catholic 76: 47.

Upchurch, Dawn M., Claire E. Dye, Laura Chyu, Ellen B. Gold, and Gail A. Greendale. 2010. Demographic, Behavioral, and Health Correlates of Complementary and Alternative Medicine and Prayer Use among Midlife Women: 2002. Journal of Women's Health 19: 23-30. [CrossRef] [PubMed]

Vanghi, Peter J. 2016. Spiritual Works of Mercy: How Do We Demonstrate Our Mercy to Others? Priest 72: 45-49. Zaleski, Philip, and Carol Zaleski. 2005. Prayer: A History; Houghton Mifflin Company. New York: Houghton Mifflin Harcourt, p. 315, ISBN 13: 978-0-618-15288-9.

C 2018 by the authors. Licensee MDPI, Basel, Switzerland. This article is an open access article distributed under the terms and conditions of the Creative Commons Attribution (CC BY) license (http://creativecommons.org/licenses/by/4.0/). 